\title{
ASYMPTOMATIC PRIMARY BREAST ANGIOSARCOMA IN 45-YEARS-OLD WOMAN
}

\author{
Edith Tenorio-Flores', Maria-del-Carmen Garcia-Blanco', Jesús Cienfuegos-Meza², \\ Leslie-Marisol González-Hermosillo33, Ernesto Roldan-Valadez 4,5 \\ 1 - Department of Radiology, Hospital Angeles Acoxpa. Mexico City, Mexico. \\ 2 - Department of Anatomic Pathology, Hospital Angeles Clinica Londes, Mexico City, Mexico. \\ 3 - Escuela de Medicina, Universidad de Guadalajara and Clinical practices in Hospital General Regional No46. Jalisco State, Mexico. \\ 4 - Hospital General de Mexico "Dr Eduardo Liceaga". Mexico City, Mexico. \\ 5 - I.M. Sechenov First Moscow State Medical University (Sechenov University), Department of Radiology. Moscow, Russia.
}

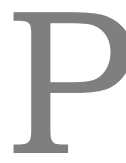

rimary breast angiosarcoma is an extremely rare tumour type $(0.05 \%$ of primary breast cancers with an incidence of 4.5 cases per million in the USA), so diagnosis can be difficult. They arise within the breast parenchyma and generally present as a breast mass. This report presents the case of a 45-year-old woman who attended the imaging department to participate in the screening program of early detection of breast cancer. A core needle biopsy revealed an angiosarcoma.

This case points to the subtle imaging findings in a lesion smaller than one centimeter (mammogram and ultrasound) that led the radiologist to perform a biopsy to find malignant breast cancer in a patient with no history of any known risk factors.

Keywords: angiosarcoma of the breast, magnetic resonance imaging, mammography, ultrasonography, metastasis.

Corresponding author: Edith Tenorio-Flores, e-mail: tenoflo@yahoo.com.mx; Ernesto RoldanValadez, e-mail: ernest.roldan@usa.net

For citation: Edith Tenorio-Flores, Maria-del-Carmen Garcia-Blanco, Jesús Cienfuegos-Meza, Leslie-Marisol González-Hermosillo, Ernesto Roldan-Valadez. Asymptomatic primary breast angiosarcoma in 45-years-old woman. REJR 2021; 11(3):185-190. DOI: 10.21569/2222-7415-2021-11-3-185190.

Received: $\quad 02.07 .21 \quad$ Accepted: $\quad 09.09 .21$

\section{БЕССИМПТОМНАЯ АНГИОСАРКОМА МОЛОЧНОЙ ЖЕАЕЗЫ У ЖЕНЩИНЫ 45 АЕТ}

\section{Элит Тенорио-Флорес ', Мария-дель-Кармен Гарсия-Бланко ', Хесус Сьенфруэгос- Меза², ^если-Марисоль Гонсалес-Эрмосильо 3 , Эрнесто РолАан-Валалес 4,5}

\footnotetext{
1 - Отдемение мучевой диагностики, больница Angeles Acoxpa. Мехико, Мексика.

2 - Отделение анатомической патологии, Госпиталь Angeles Клиники Londes, Мехико, Мексика.

3 - Университет Гвадалахары и больница общего профиля № 46. Штат Халиско, Мексика.

4 - ГАавный госпиталь Мексики " Dr Eduardo Liceaga ". Мехико, Мексика.

5 - Первый МГМУ им. И.М. Сеченова Минздрава России (Сеченовский Университет). Москва, Россия.
}

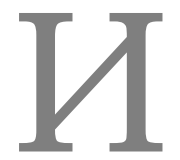

Первичная ангиосаркома молочной железы является чрезвычайно редким типом опухоли $(0,05 \%$ от первичного рака молочной железы с частотой 4,5 случая на мим^ион в США), поэтому диагностика бывает затруднена. Ангиосаркома возникает в паренхиме молочной железы и обычно представляют собой образование. В данном клиническом наблюдении представцен случай 45-летней женщины, которая обратилась в отдемение мучевой диагностики дмя участия в программе скрининга раннего выявления рака мо- 


\section{RUSSIAN ELECTRONIC JOURNAL OF RADIOLOGY}

мочной жемезы. Биопсия стержневой иглой выявила ангиосаркому.

Этот клинический случай указывает на сложности при визуализации поражений размером менее одного сантиметра (при маммографии и УЗИ), которые побуждают рентгенологов выполнять биопсию, чтобы обнаружить змокачественное новообразование молочной железы у пациентки без известных факторов риска в анамнезе.

КАючевые слова: ангиосаркома молочной железы, магнитно-резонансная томография (МРТ), маммография, эхография, метастазы.

Контактный автор: Эдит Тенорио-Фцорес, e-mail: tenoflo@yahoo.com.mx; Эрнесто РолданВаладес, e-mail: ernest.roldan@usa.net

Для иитирования: Эдит Тенорио-Флорес, Мария-дель-Кармен Гарсия-Бланко, Хесус СьенфуэгосМеза, Аесли-Марисоль Гонсалес-Эрмосильо, Эрнесто Ролдан-Валадес. Бессимптомная ангиосаркома молочной железы у женшины 45 лет. REJR 2021; 11(3):185-190. DOI: 10.21569/2222-74152021-11-3-185-190.
Статья получена:
02.07.21
Статья принята:
09.09.21

\section{I} ntroduction.

Breast angiosarcoma is a rare malignant neoplasm arising from endothelial cells lining blood or lymphatic vessels $[1,2]$. The breast is one of the most common sites for developing an angiosarcoma [3]. It is divided into primary and secondary types depending on the cause of the tumours. It is a sporadic type of tumour $(0.05 \%$ of primary breast cancers), so reaching a diagnosis can be challenging [4]. Furthermore, the recurrence rate is $67 \%$ making essential early detection, knowing the tumour size, and clear margins to determine the patient outcome [1].

Available literature reports focus on postradiation angiosarcomas, but only a small series of patients affected by primary angiosarcoma are presented. Outcomes in breast AS consist mainly of retrospective studies, and optimal management remains a challenge $[2,4]$.

This report aimed to show a brief review of the mammographic and ultrasonographic characteristics of primary breast angiosarcoma that helped specialize radiologists to identify this type of lesion in a young asymptomatic woman.

Case presentation.

A 45-year-old woman with no relevant personal and family history underwent mammography for early detection of breast cancer. The mammogram presented with a diffuse hard mass and fullness in the lower internal quadrant and middle third of the left breast (Fig. $1 \mathrm{~A}-\mathrm{C}$ ).

Ultrasonography revealed a hypoechoic nodule with lobulated border with echogenic halo measuring $4.2 \times 5.3 \times 4.0 \mathrm{~mm}$ with central vascularity (Fig. 2 A-E).

Core needle biopsy revealed a low-grade an- giosarcoma with smooth, well-formed vascular channels demonstrating a permeative growth pattern that dissects through the mammary parenchyma (Fig. 3 A-D). Based on the imaging findings and biopsy, a diagnosis of breast angiosarcoma was made.

\section{Discussion.}

Clinical relevance of this report.

Knowing the imaging features of breast angiosarcoma, it is essential for clinicians attending patients with breast pathology to perform a correct diagnosis considering the aggressive behaviour and poor prognosis of this kind of tumour.

Aetiology.

Primary breast angiosarcoma occurs sporadically with unknown aetiology. The secondary one is radiation-induced angiosarcoma, which arises in the dermal and subcutaneous layers of the skin and the average latency period is $5-6$ years $[5,6]$. The typical patient with primary breast angiosarcoma is a young woman with no previous cancer history with dense breast parenchyma $[1,4]$. Other signs such as a bluish or purplish discolouration indicate vascular tumours, similar to mastitis. In contrast with secondary angiosarcoma, the mean age is about 65 years $[5,7]$.

Classification.

Primary angiosarcoma tends to spread hematogenously and shows a high propensity for metastasis toward bone, lung and liver; nevertheless, angiosarcoma does not typically distribute through the lymphatic system $[2,8]$.

The breast sarcoma family is represented mainly by fibrosarcomas, angiosarcomas and malignant fibrous histiocytomas and is usually presents as an insufficiently defined mass in breast parenchyma characterized by rapid growth and 


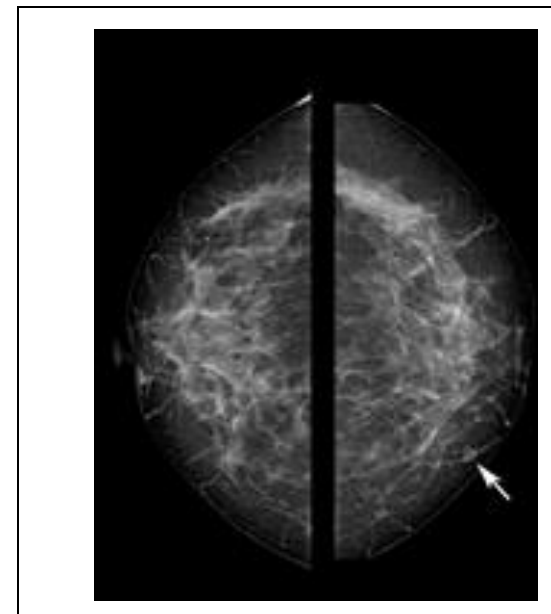

Fig. 1 a (Рис. 1 a)

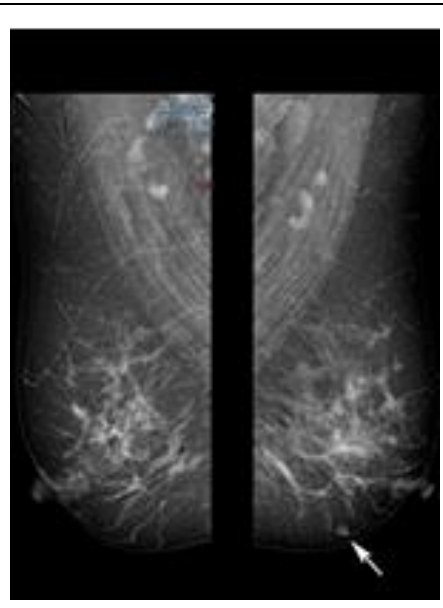

Fig. 1 b (Рис. 1 б)

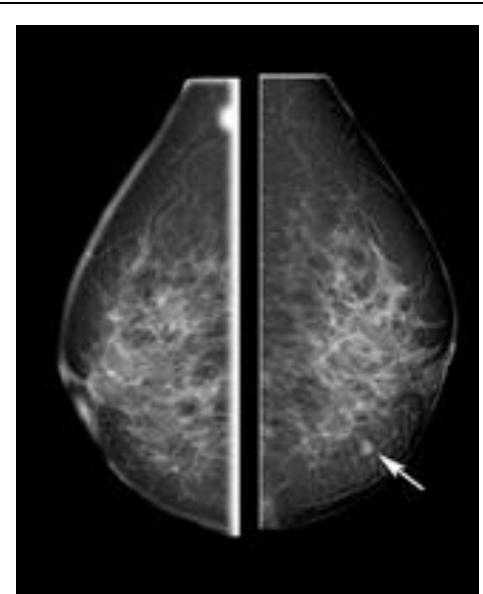

Fig. 1 с (Рис. 1 в)

Fig. 1. Mammograms. A - craniocaudal view, B - mediolateral oblique view, C - laterals de $90^{\circ}$ view.

A round, isodense nodule with irregular border in the lower internal quadrant and middle third of the left breast (white arrows).

Рис. 1. Маммограммы, А - краниокауАальная проекция, В - меАиолатеральная косая проекция; C - $90^{\circ}$ боковая проекция.

Визуализируется круглый изоденсный узел с неровными границами в нижнем внутреннем квадранте и средней трети мевой молочной железы (белые стрелки).

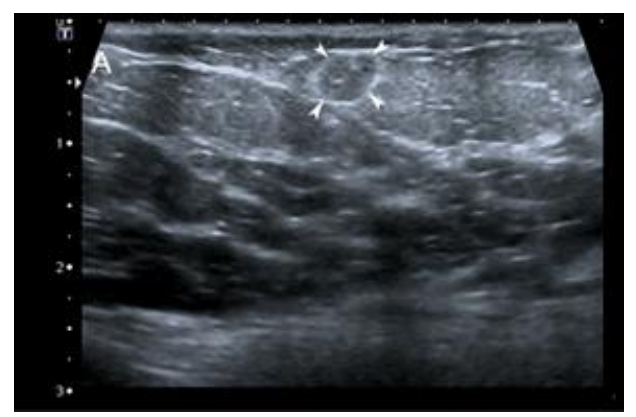

Fig. 2 a (Рис. 2 a)

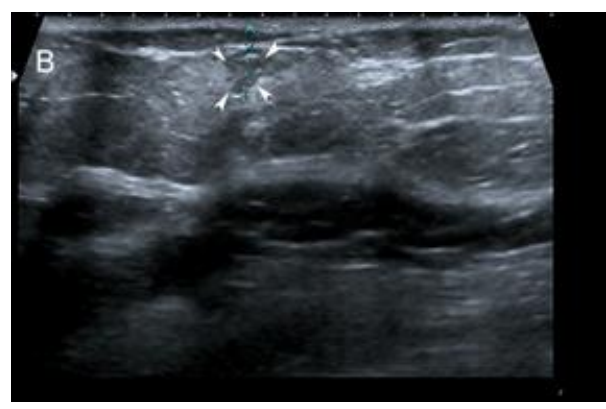

Fig. 2 b (Рис. 2 б)

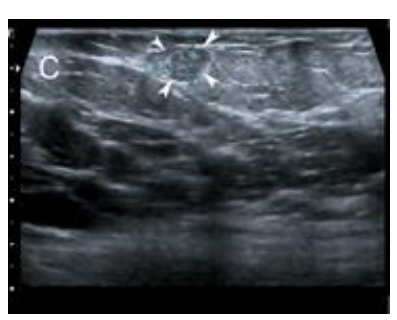

Fig. 2 с (Рис. 2 в)

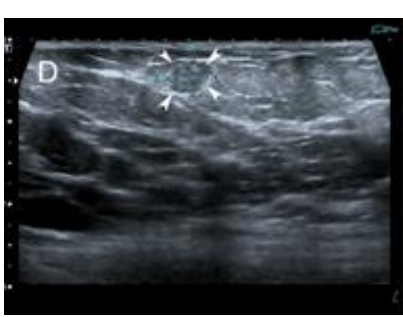

Fig. $2 \mathrm{~d}$ (Рис. 2 r)

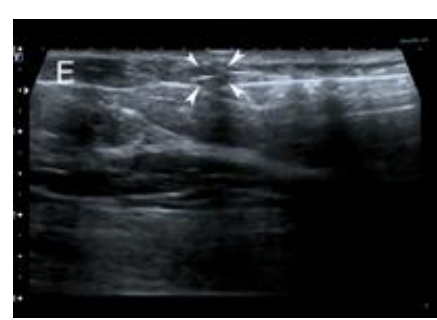

Fig. 2 e (Рис. 2 A)

Fig. 2. US, breast.

A breast ultrasound shows a hypoechoic nodule with a lobulated border with an echogenic halo measuring $4.2 \times 5.3 \times 4.0 \mathrm{~mm}$ with central vascularity (white arrowheads).

\section{Рис. 2. Узи молочной железы.}

Визуализируется гипоэхогенный узел с дольчатой границей, с эхогенным ореолом, размером 4,2х5,3х4,0 мм, с центральной васкуляризацией (белые стрелки). 


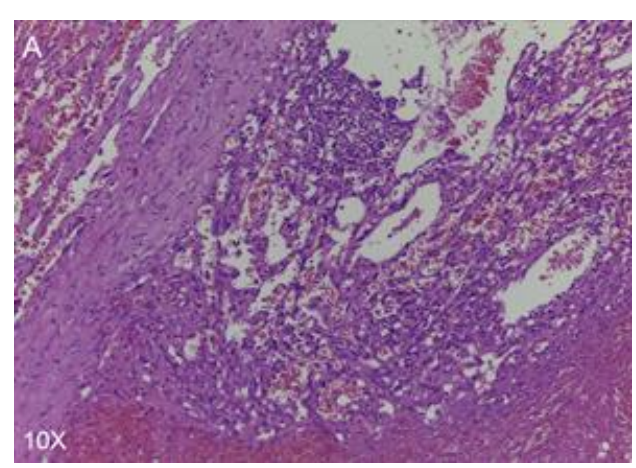

Fig. 3 a (Рис. 3 a)

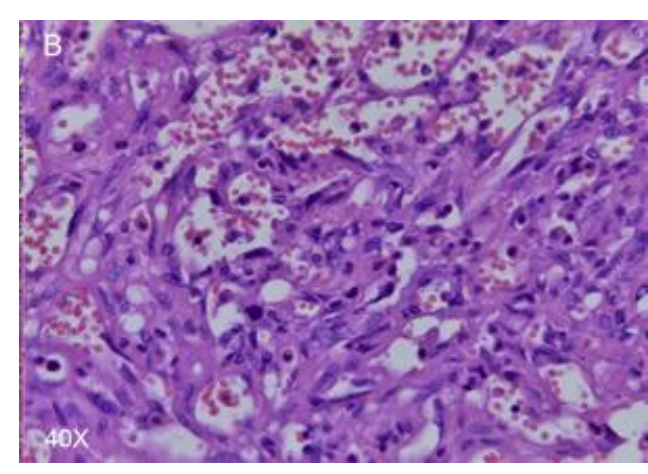

Fig. 3 b (Рис. 3 б)

\section{Fig. 3. Microsection.}

a - angiosarcoma is characterized by anastomosing vascular channels with an infiltrative growth pattern (H\&E, 10x).

b - at higher magnification neoplasic cells show pleomorphism and variable mitotic activity (H\&E, 40x).

\section{Рис. 3. Микропрепарат.}

а - ангиосаркома характеризуется анастомозированием сосудистых каналов с инфильтративным типом роста (гематоксилин-эозин, 10х).

б - при большем увеличении опухолевые клетки демонстрируют плеоморфизм и различную митотическую активность (гематоксилин-эозин, 40х).

most commonly presents as painless and rapidly growing palpable mass $[4,8]$.

The three histopathological patterns have been described type I, characterized by vascular channels invading the tissue with scarce endothelial proliferation; type II, presenting papillary endothelial components and type III, endothelial features, necrosis and haemorrhage [4].

Clinical presentation.

The correct diagnosis of a breast sarcoma is hugely relevant due to its aggressive behaviour and poor prognosis; moreover, it is also characterized by local recurrence rates ranging from 54$92 \%$ [9]. Altogether, breast angiosarcoma has a 5year survival rate of approximately 33\% [7]. The imaging findings are not pathognomonic but can identify the site of percutaneous biopsy, which is always required to make the definitive diagnosis.

\section{Imaging findings.}

Although mammography and US are the most commonly used diagnostic tools, the method of choice is considered magnetic resonance imaging (MRI) that can show typical malignant signs (heterogeneous mass with low signal intensity on T1-weighted and high signal intensity T2-weighted images) [1]. Enhancement of the mass depends on the tumour grade; low-grade angiosarcoma shows progressive enhancement, besides high-grade angiosarcoma shows rapid enhancement and large vessels [3, 4].

The mammography findings are nonspecific; it can be a solitary well-defined, or ill-defined mass, it is no associated with calcification or speculation the most time. It can present several findings: well-defined round nodules, a large asymmetric dense shadow that affects the whole breast, trabecular breast patterns, thickened local vessels, cloudy subcutaneous fat, and skin thickening [7]. Ultrasonography is a tool for confirmation of a lesion when a palpable abnormality mass is found. Diffuse, abnormal, hyperechogenic and hypoechogenic regions with hypervascularity are detected with colour Doppler US [3].

Treatment.

The treatment for breast angiosarcoma includes surgery, chemotherapy or radiation therapy. In current years, mastectomy is the main recommended curative intervention, and radical resection is associated with better outcomes [2].

With a lack of prospective studies, the optimal management is based on expert opinion. Both of the subtypes of breast angiosarcoma are managed similarly, with surgical excision. Complete resection with negative margins is the goal of surgical intervention [10].

The role of chemotherapy is unclear and had no survival impact in both breast angiosarcoma groups $[10,11]$. Nevertheless, the role of adjuvant chemotherapy remains questionable, except in high-grade tumours where it has shown to be more beneficial [10].

Radiation therapy has been suggested to 


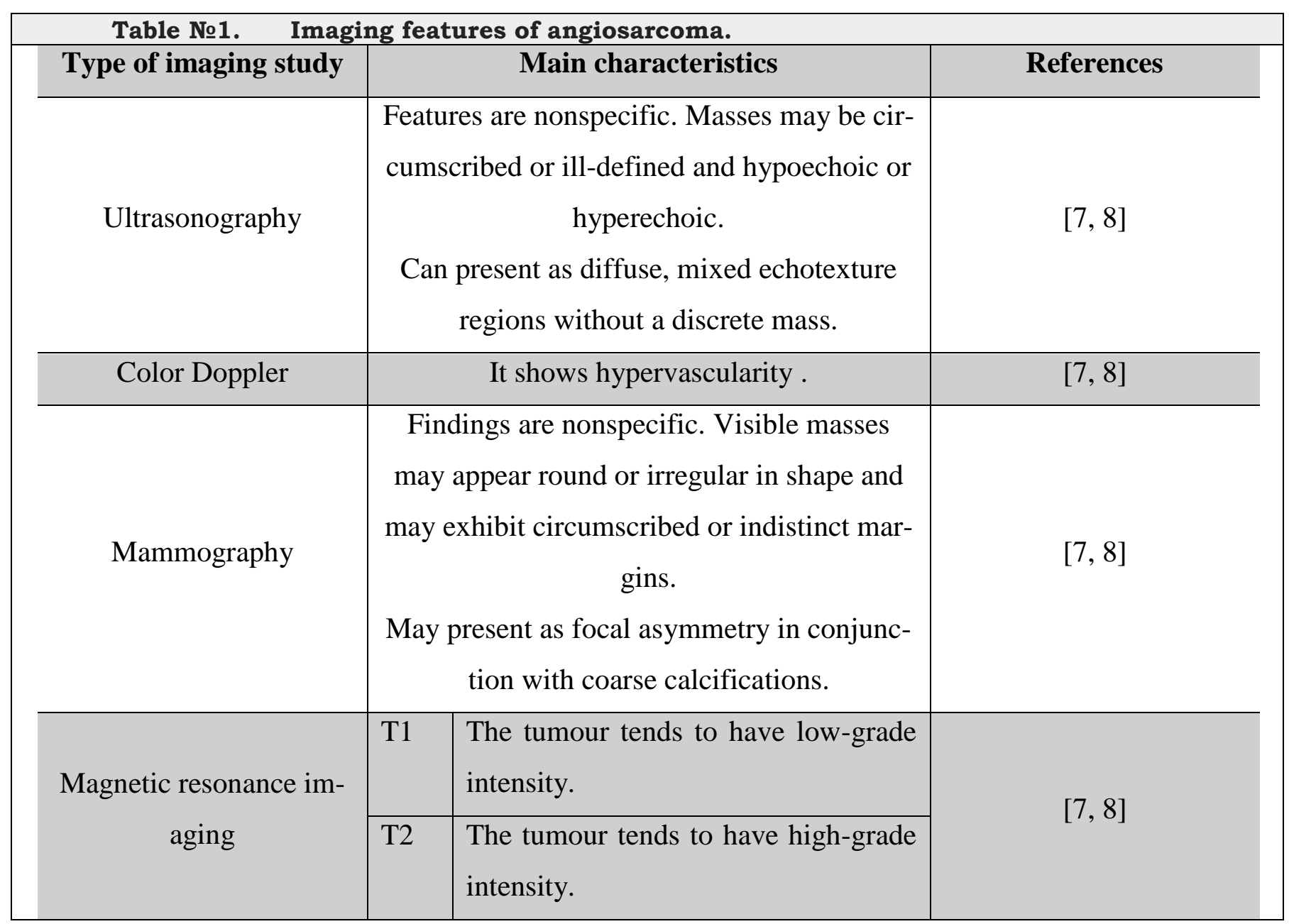

improve local control, even in the irradiation setting [2]. Radiotherapy is considered for angiosarcoma size $>5 \mathrm{~cm}$, high-grade tumours and patients with positive margins [11]. Currently, it is believed that more aggressive surgery with mastectomy concurs clinical advantage with more regional control [10].

Prognosis factors.

The prognosis is related to the tumour size, grade, the resection margin status and mitotic index defining the tumour grade. Most papers show how a positive margin is strictly connected with both local relapse and worst survival [4].

Conclusion.

\section{References:}

1. Aljohani B, Al-Twajeri T, Alameer A, Alzaydi T, Alawwad S, Anwar I, Alshabanh M, Tulba A, Almalik O (2017) Clinicopathological features of breast angiosarcoma: A 16-years singleinstitution experience. Int $J$ Surg Case Rep. 2017; 37: 211-215. doi:10.1016/j.ijscr.2017.06.040

2. Gutkin PM, Ganjoo KN, Lohman M, von Eyben R, Charville GW, Nazerali RS, Dirbas FM, Horst KC (2020) Angiosarcoma of the Breast: Management and Outcomes. Am J Clin Oncol. 2020; 43 (11): 820-825. doi:10.1097/coc.0000000000000753

3. Glazebrook KN, Magut MJ, Reynolds C (2008) Angiosarcoma
In summary, breast angiosarcoma is a rare but aggressive tumour with a 5-year overall survival of $44 \%$ with a high recurrence rate. It is necessary to use multimodality imaging methods, as well as for the treatment from the extent of primary resection to making local excision. In the future, a better knowledge of the molecular basis of this tumour will improve the treatment and help to develop targets of therapies for a better patient's prognosis.

\section{Acknowledgements.}

L.M.G.H. was a research fellow at directorate of research of HGMEL under the supervision of E.R.V. in 2021.

of the breast. AJR Am J Roentgenol. 2008; 190 (2): 533-538. doi:10.2214/ajr.07.2909

4. Bordoni D, Bolletta E, Falco G, Cadenelli P, Rocco N, Tessone A, Guarino S, Accurso A, Amato B, Magalotti C (2016) Primary angiosarcoma of the breast. Int J Surg Case Rep. 2016; 20s (Suppl): 12-15. doi:10.1016/j.ijscr.2016.02.003

5. Varghese B, Deshpande P, Dixit S, Koppiker CB, Jalnapurkar $N$ (2019) Primary Angiosarcoma Of the Breast: A Case Report. J Radiol Case Rep. 2019; 13 (2): 15-25. doi:10.3941/jrcr.v13i2.3449 


\section{RUSSIAN ELECTRONIC JOURNAL OF RADIOLOGY}

6. Cassou-Mounat T, Champion L, Bozec L, Laurence V, Huchet V, Luporsi M, Jehanno N (2019) Primary and Secondary Breast Angiosarcoma: FDG PET/CT Series. Clin Nucl Med. 2019; 44 (1): e33-e35. doi:10.1097/rlu.0000000000002334

7. Wu WH, Ji QL, Li ZZ, Wang QN, Liu SY, Yu JF (2019) Mammography and MRI manifestations of breast angiosarcoma. BMC Womens Health. 2019; 19 (1): 73. doi:10.1186/s12905-0190769-3

8. Im S, Chae BJ, Kim SH, Kang BJ, Song BJ, Lee A (2019) Primary angiosarcoma of the breast: a case report. Int $J$ Clin Exp Pathol. 2019; 12 (2): 664-668

9. Gervais MK, Burtenshaw SM, Maxwell J, Dickson BC, Catton CN, Blackstein M, McCready D, Escallon J, Gladdy RA (2017)
Clinical outcomes in breast angiosarcoma patients: A rare tumor with unique challenges. $J$ Surg Oncol. 2017; 116 (8): 1056-1061. doi:10.1002/jso.24780

10. Abdou Y, Elkhanany A, Attwood K, Ji W, Takabe K, Opyrchal $M$ (2019) Primary and secondary breast angiosarcoma: single center report and a meta-analysis. Breast Cancer Res Treat. 2019; 178 (3): 523-533. doi:10.1007/s10549-01905432-4

11. Masai K, Kinoshita T, Jimbo K, Asaga S, Hojo T (2016) Clinicopathological features of breast angiosarcoma. Breast Cancer. 2016; 23 (5): 718-723. doi:10.1007/s12282-015-0630-y. 